\title{
Faktor usia dan obesitas berhubungan dengan kejadian hipertensi di Puskesmas Sungai Pinyuh
}

\author{
Velvia Ramona ${ }^{1, *}$, Sari Eka Pratiwi ${ }^{2}$, Iit Fitrianingrum ${ }^{2}$ \\ ${ }^{I}$ Program Studi Kedokteran, Fakultas Kedokteran, Universitas Tanjungpura, Kalimantan Barat, Indonesia \\ ${ }^{2}$ Departemen Biologi dan Patobiologi, Fakultas Kedokteran, Universitas Tanjungpura, Kalimantan Barat, Indonesia \\ *Korespondensi: velviaramona18@gmail.com
}

\begin{abstract}
Abstrak
Latar belakang: Hipertensi adalah salah satu penyakit tidak menular penyebab kematian penyakit jantung di dunia sebesar 45\%. Hipertensi menempati posisi tertinggi kedua di Kabupaten Mempawah. Kabupaten Mempawah merupakan kabupaten urutan kedua dengan kejadian hipertensi tertinggi di Kalimantan Barat. Penduduk Kabupaten Mempawah memiliki karakteristik yang berpotensi untuk terkena hipertensi yakni penduduk terbanyak dengan kelompok tingkat pendidikan rendah dan tidak bekerja. Tujuan penelitian ini adalah mengetahui hubungan antara faktor usia dan obesitas serta faktor lain terhadap kejadian hipertensi di Puskesmas Sungai Pinyuh. Metode: penelitian ini merupakan penelitian analitik observasional dengan desain cross sectional. Cara pemilihan sampel adalah non-probability sampling secara consecutive sampling. Sebanyak 61 responden diwawancara serta diukur berat dan tinggi badannya. Data dianalisis menggunakan uji Chi-square, uji Kolmogorov-Smirnov, dan uji Fisher. Hasil: Hasil uji Chi-square menunjukkan secara statistik terdapat hubungan yang bermakna antara usia $(\mathrm{p}=0,012)$ dan obesitas $(\mathrm{p}=0,032)$ dengan kejadian hipertensi, sedangkan jenis kelamin, pekerjaan, tingkat pendidikan, etnis, riwayat penyakit keluarga, merokok dan diabetes melitus tidak memiliki hubungan yang bermakna dengan kejadian hipertensi. Kesimpulan: Terdapat hubungan antara usia dan obesitas terhadap kejadian Hipertensi di Puskesmas Sungai Pinyuh.
\end{abstract}

Kata kunci: hipertensi, faktor risiko, kejadian hipertensi

\section{Relationship between age and obesity with the incidence of hypertension in Puskesmas Sungai Pinyuh}

\begin{abstract}
Background: Hypertension is a non-communicable disease that accounts for $45 \%$ of deaths related to cardiac diseases worldwide. Hypertension is the second most common disease in Mempawah District, and Mempawah District is the second-ranked district with the highest incidence of hypertension in West Kalimantan. The population of Mempawah District has the potential to be affected by hypertension because of the large number of people with low education and unemployment. This research aims to evaluate the relationship between age, obesity, and other factors with hypertension in Puskesmas Sungai Pinyuh. Methods: This research was an observational analytic study using a cross-sectional design. The sample was chosen using the consecutive sampling method. Sixty-one respondents were interviewed, and their body weights and heights were measured. Data were analyzed using Chi-square, Kolmogorov-Smirnov, and Fisher test. Results: Chi-square test showed that there was a statistically significant relationship between age $(p=0.012)$ and obesity $(p=0.032)$ with hypertension. While gender, occupation, education level, ethnicity, family history, smoking habit, and diabetes mellitus did not show a significant relationship with hypertension. Conclusions: There is a relationship between age and obesity with hypertension in Puskesmas Sungai Pinyuh.
\end{abstract}

Keywords: hypertension, risk factors, incidence of hypertension

\section{Pendahuluan}

Hipertensi atau tekanan darah tinggi adalah suatu keadaan dimana terjadi peningkatan tekanan sistolik yang melebihi $140 \mathrm{mmHg}$ dan tekanan diastolik yang melebihi dari $90 \mathrm{mmHg} .{ }^{1}$ Hipertensi merupakan salah 
satu penyebab kematian pada penyakit jantung di dunia sebesar $45 \%$. Hipertensi adalah penyakit tidak menular yang dijuluki sebagai silent killer. Negara berkembang menunjukkan angka yang lebih besar terhadap kejadian hipertensi dibandingkan dengan negara maju. ${ }^{2}$

Menurut laporan World Health Organization (WHO) tentang penyakit tidak menular pada negara tahun 2018, didapatkan bahwa prevalensi tertinggi hipertensi berdasarkan pendapatan negara terdapat pada wilayah Afrika yaitu sebesar $27 \%$ sedangkan wilayah Amerika merupakan negara dengan prevalensi terendah sebesar $18 \%$. Proporsi hipertensi pada tahun 2015 menunjukkan bahwa pada negara berpenghasilan rendah mencapai $28 \%$ sedangkan pada negara berpenghasilan tinggi yaitu sebesar $18 \%$. Hal ini menunjukkan bahwa telah terjadi peningkatan jumlah orang dewasa yang terkena hipertensi dari 548 juta pada tahun 1975 menjadi 1,13 miliar. $^{3}$

Proporsi hipertensi pada penduduk yang berusia di atas 17 tahun di Indonesia mengalami peningkatan angka proporsi yang cukup besar dalam jangka waktu lima tahun sejak 2013 yaitu dari sebesar 25,8\% menjadi $34,1 \%$. Prevalensi tertinggi hipertensi terletak pada Provinsi Kalimantan Selatan, Jawa Barat, Kalimantan Timur, Jawa Tengah dan Kalimantan Barat. ${ }^{4}$

Profil kesehatan Kalimantan Barat tahun 2017 menyatakan bahwa hipertensi menempati posisi ketiga dalam sepuluh besar penyakit tertinggi di Kalimantan Barat setelah influenza dan diare. Proporsi kasus hipertensi di Kalimantan Barat yaitu sebesar $23,5 \%$. Berdasarkan data tersebut, diketahui pada tiga posisi tertinggi yang memiliki persentase hipertensi yang tinggi di kota atau kabupatennya yaitu Kabupaten Sintang, Kabupaten Mempawah dan Kota Singkawang. ${ }^{5}$

Kabupaten Mempawah memiliki profil kependudukan dengan penduduk terbanyak terdapat pada kelompok tingkat pendidikan rendah sebesar $37,35 \%$, status pekerjaan tidak bekerja $29 \%$ dan penduduk dengan usia pendidikan 18 sampai 22 tahun sebesar 25,73\%. Selain itu, Kabupaten Mempawah juga memiliki keberagaman suku diantaranya yakni Melayu, Tionghoa, Madura, Dayak, Bugis, Jawa dan Sunda. Penduduk terbanyak Kabupaten Mempawah terletak pada Kecamatan Sungai Pinyuh sebesar 21,30\%. Kecamatan Sungai Pinyuh terdiri atas 8 Desa dengan 1 kelurahan. ${ }^{6,7}$

Profil Kesehatan Kabupaten Mempawah tahun
2017 menyatakan bahwa proporsi kejadian hipertensi memiliki persentase sebesar 29,27 \%. ${ }^{6}$ Kabupaten Mempawah menempatkan hipertensi pada posisi tertinggi kedua setelah infeksi akut saluran pernapasan atas dengan jumlah kunjungan sebanyak 11.761 yang diperoleh berdasarkan pasien yang berkunjung ke Puskesmas. ${ }^{6}$ Kabupaten Mempawah memiliki 12 puskesmas rawat jalan dan dua puskesmas rawat inap yang bertujuan untuk mendukung pelayanan kesehatan di masing-masing kecamatan. Puskesmas rawat inap tersebut terletak di Sungai Pinyuh dan Jungkat. ${ }^{7}$ Dari kedua puskesmas rawat inap tersebut, Puskesmas Sungai Pinyuh memiliki angka kejadian hipertensi yang lebih besar yakni 280 orang.

Hipertensi memiliki beberapa faktor risiko seperti usia, jenis kelamin, riwayat penyakit keluarga, kebiasaan merokok, indeks massa tubuh, dan kebiasaan konsumsi alkohol. WHO menyatakan bahwa secara global didapatkan faktor risiko hipertensi berdasarkan jenis kelamin dinyatakan bahwa satu dari empat laki-laki dan satu dari lima perempuan memiliki tekanan darah yang tinggi. ${ }^{3}$ Berdasarkan penelitian sebelumnya, didapatkan hasil bahwa merokok dan diabetes mellitus merupakan salah satu faktor risiko yang memiliki hubungan terhadap kejadian hipertensi. ${ }^{8,9}$ Adapun perbedaan penelitian ini dengan yang sudah pernah dilakukan yakni adanya variabel penelitian etnis yang juga dihubungkan dengan kejadian hipertensi. Selain itu, penelitian ini dilakukan di puskesmas dengan angka kejadian hipertensi tertinggi di Kabupaten Mempawah. yaitu Puskesmas Sungai Pinyuh.

Berdasarkan uraian di atas, maka penulis ingin melakukan penelitian ini dengan tujuan mengetahui hubungan antara berbagai faktor seperti usia, jenis kelamin, riwayat penyakit keluarga, kebiasaan merokok, indeks massa tubuh dan riwayat diabetes melitus terhadap kejadian hipertensi.

\section{Metode}

Penelitian ini merupakan penelitian yang bersifat analitik observasional dengan desain penelitian cross-sectional. Penelitian dilakukan pada tahun 2019 di Puskesmas Sungai Pinyuh. Pengumpulan data dilakukan dengan menggunakan daftar tilik, rekam medis dan pengukuran berat badan serta tinggi badan. Responden penelitian adalah pasien rawan jalan di poli umum yang berkunjung ke 
puskesmas dan telah memenuhi kriteria penelitian yaitu sebanyak 61 orang. Kriteria inklusi pada penelitian ini adalah pasien merupakan pasien rawat jalan yang berkunjung di Puskesmas Rawat Inap Sungai pinyuh, pasien sudah pernah berobat di puskesmas tersebut, pasien berusia $\geq 18$ tahun dan bersedia menjadi responden. Adapun Kriteria eksklusi pada penelitian ini adalah pasien sedang hamil, pasien memiliki riwayat penyakit ginjal, pasien memiliki penyakit tiroid dan pasien tidak dapat berkomunikasi dengan baik.

Pada penelitian ini digunakan uji statistik Chi square dengan uji alternatifnya pada variabel yang tidak memenuhi syarat. Variabel yang menggunakan hasil uji Chi-square adalah jenis kelamin, pekerjaan, obesitas dan riwayat keluarga. Sedangkan variabel usia dan tingkat pendidikan menggunakan hasil uji Mann-Whitney dan variabel etnis menggunakan uji Kolmogorov-Smirnov. Adapun variabel merokok dan DM menggunakan hasil uji Fisher.

\section{Hasil}

Penelitian ini dilakukan di Puskesmas Rawat Inap Sungai Pinyuh pada bulan Oktober tahun 2019 selama 4 hari. Selama penelitian diambil 61 orang pasien rawat jalan yang berkunjung ke poli umum secara berurutan sesuai jumlah yang diperlukan dan kriteria inklusi yang telah ditentukan. Pengumpulan data dilakukan dengan wawancara langsung kepada pasien menggunakan daftar tilik dan catatan diagnosis pada rekam medis. Variabel penelitian ini adalah faktor risiko kejadian hipertensi yang terdapat pada pasien meliputi usia, jenis kelamin, pekerjaan, tingkat pendidikan, etnis, obesitas, riwayat keluarga, merokok, alkohol dan riwayat diabetes mellitus.

Pada penelitian ini diambil 61 responden yang telah memenuhi kriteria inklusi dan eksklusi. Dari 61 responden tersebut ditemukan lebih banyak pasien yang tidak mengalami hipertensi yakni sebanyak 40 responden dengan persentase 65,6\% sedangkan responden yang mengalami hipertensi hanya 21 responden dengan persentase kejadian sebesar 34,4\%. Adapun untuk karakteristik responden pada penelitian ini terbanyak berada pada kelompok responden dewasa tua $(83,6 \%)$, laki-laki $(63,9 \%)$, tidak bekerja $(63,9 \%)$, pendidikan rendah $(67,2 \%)$, Melayu $(49,2 \%)$, tidak obesitas $(73,8 \%)$, riwayat keluarga $(54,1 \%)$, tidak merokok $(82 \%)$, riwayat diabetes melitus $(91,8 \%)$.

Tabel 1. Karakteristik subjek penelitian

\begin{tabular}{|c|c|c|c|c|c|c|c|c|}
\hline \multirow{3}{*}{ Variabel } & \multirow{3}{*}{ Kelompok } & \multicolumn{4}{|c|}{ Kejadian Hipertensi } & \multicolumn{2}{|c|}{ Jumlah } & \multirow{3}{*}{$\begin{array}{c}\text { Nilai } \\
\text { Probabilitas }\end{array}$} \\
\hline & & \multicolumn{2}{|c|}{ Tidak } & \multicolumn{2}{|c|}{ Ya } & \multirow{2}{*}{$\mathrm{N}$} & \multirow{2}{*}{$\%$} & \\
\hline & & $\mathrm{N}$ & $\%$ & $\mathrm{~N}$ & $\%$ & & & \\
\hline \multirow[t]{3}{*}{ Usia } & Dewasa Muda & 5 & 71.4 & 2 & 28.6 & 7 & 100 & $0.012 *$ \\
\hline & Dewasa Tua & 33 & 64.7 & 18 & 35.3 & 51 & 100 & \\
\hline & Lanjut Usia & 2 & 66.7 & 1 & 33.3 & 3 & 100 & \\
\hline \multirow[t]{2}{*}{ Jenis Kelamin } & Laki-laki & 15 & 68.2 & 7 & 31.8 & 22 & 100 & 0.747 \\
\hline & Perempuan & 25 & 64.1 & 14 & 35.9 & 39 & 100 & \\
\hline \multirow[t]{2}{*}{ Pekerjaan } & Bekerja & 20 & 71.4 & 8 & 28.6 & 28 & 100 & 0.375 \\
\hline & Tidak bekerja & 20 & 60.6 & 13 & 39.4 & 33 & 100 & \\
\hline \multirow[t]{3}{*}{ Tingkat Pendidikan } & Rendah & 23 & 56.1 & 18 & 43.9 & 41 & 100 & 0.067 \\
\hline & Menengah & 14 & 82.4 & 3 & 17.6 & 17 & 100 & \\
\hline & Tinggi & 3 & 100 & 0 & 0 & 3 & 100 & \\
\hline \multirow[t]{4}{*}{ Etnis } & Melayu & 18 & 60 & 12 & 40 & 30 & 100 & 0.0987 \\
\hline & Tionghoa & 5 & 62.5 & 3 & 37.5 & 8 & 100 & \\
\hline & Dayak & 1 & 100 & 0 & 0 & 1 & 100 & \\
\hline & Lainnya & 16 & 72.7 & 6 & 27.3 & 22 & 100 & \\
\hline \multirow[t]{2}{*}{ Obesitas } & Tidak & 33 & 73.3 & 12 & 26.7 & 45 & 100 & $0.032 *$ \\
\hline & Ya & 7 & 43.8 & 9 & 56.2 & 16 & 100 & \\
\hline \multirow[t]{2}{*}{ Riwayat penyakit keluarga } & Tidak & 20 & 71.4 & 8 & 28.6 & 28 & 100 & 0.375 \\
\hline & Ya & 20 & 60.6 & 13 & 39.4 & 33 & 100 & \\
\hline \multirow[t]{2}{*}{ Merokok } & Tidak & 34 & 68 & 16 & 32 & 50 & 100 & 0.488 \\
\hline & $\mathrm{Ya}$ & 6 & 54.5 & 5 & 45.5 & 11 & 100 & \\
\hline \multirow[t]{2}{*}{ Diabetes mellitus } & Tidak & 38 & 67.9 & 18 & 32.1 & 56 & 100 & 0.329 \\
\hline & $\mathrm{Ya}$ & 2 & 40 & 3 & 60 & 5 & 100 & \\
\hline
\end{tabular}

Keterangan: *terdapat hubungan antara bermakna antara faktor terhadap kejadian hipertensi 
Berdasarkan uji statistik didapatkan terdapat hubungan bermakna antara usia dan obesitas terhadap kejadian hipertensi di Puskesmas Sungai Pinyuh. Berdasarkan hasil uji statistic, didapatkan bahwa variabel jenis kelamin, pekerjaan, tingkat pendidikan, etnis, riwayat penyakit keluarga, kebiasaan merokok, dan diabetes melitus tidak ditemukan adanya hubungan yang bermakna terhadap kejadian hipertensi.

\section{Pembahasan}

Hasil penelitian menunjukkan berdasarkan jenis kelamin didapatkan bahwa pasien hipertensi pada kelompok perempuan lebih banyak mengalami hipertensi dibandingkan dengan pasien laki-laki sebanyak 35,9\% dengan hasil uji statistik pada penelitian ini menunjukkan tidak terdapat hubungan antara jenis kelamin responden terhadap kejadian hipertensi. Hasil ini berbanding terbalik dengan penelitian oleh Muhammad yang didapatkan laki-laki lebih banyak mengalami hipertensi dengan persentase $62,5 \%$ dan penelitian oleh Sartik yakni sebesar 25,7\%. ${ }^{10,11}$ Penelitian Everett dan Zajacova menyatakan adanya pengaruh hormon yang dimiliki oleh perempuan yang berfungsi sebagai pertahanan yakni adanya pengaruh hormon estrogen. ${ }^{12}$

Pengelompokkan berdasarkan variabel pekerjaan didapatkan bahwa pasien hipertensi lebih banyak pada individu yang tidak bekerja sebesar 39,4\% dan tidak terdapat hubungan bermakna terhadap kejadian hipertensi. Hal ini berbanding terbalik dengan penelitian oleh Sartik yang didapatkan pasien hipertensi lebih banyak memiliki status bekerja dengan persentase $24,16 \% .^{10}$ Pada penelitian ini tidak ditemukan adanya hubungan yang disebabkan karena perbedaan antara jenis pekerjaan atau lama jam kerja yang dilakukan dalam kehidupan sehari-hari.

Hasil uji statistik pada penelitian ini menunjukkan tidak terdapat hubungan antara tingkat pendidikan responden terhadap kejadian hipertensi. Hasil ini berbanding terbalik dengan hasil penelitian oleh Sartik di Palembang pada tahun $2017 .{ }^{10}$ Terdapat pengaruh tingkat pendidikan terhadap faktor sosial seperti pekerjaan yang berkaitan dengan tekanan pekerjaan atau jam kerja panjang yang dapat memberikan efek negatif sehingga dapat berkaitan dengan stress yang mungkin dimiliki oleh antar individunya. ${ }^{13}$
Karakteristik pasien yang dikelompokkan berdasarkan etnis didapatkan bahwa suku Melayu memiliki angka kejadian tertinggi dengan persentase sebesar $40 \%$. Hasil uji statistik pada penelitian ini menunjukkan tidak terdapat hubungan antara etnis responden terhadap kejadian hipertensi. Penelitian oleh Bell menghipotesiskan bahwa perbedaan etnis dalam peluang hipertensi akan berkurang dengan meningkatnya dukungan sosial ${ }^{14}$

Genetik juga berpengaruh terhadap kejadian hipertensi. Berdasarkan ada atau tidaknya riwayat penyakit keluarga pada pasien hipertensi didapatkan bahwa pasien yang memiliki riwayat penyakit keluarga lebih banyak mengalami hipertensi sebanyak $39,4 \%$. Pada penelitian ini tidak ditemukan adanya hubungan bermakna terhadap kejadian hipertensi. Hasil berbanding terbalik dengan hasil yang didapatkan dari penelitian oleh Muhammad dengan persentase $52,17 \%$ bahwa hipertensi lebih banyak terjadi pada kelompok responden yang tidak ada riwayat keluarga. ${ }^{11}$

Pasien hipertensi yang memiliki kebiasaan merokok pada penelitian ini didapatkan lebih sedikit daripada yang tidak merokok. Persentase pasien hipertensi pada penelitian ini lebih tinggi pada kelompok responden dengan kebiasaan merokok yaitu 76,19\%. Hasil ini berbanding lurus Sartik yakni dengan persentase sebesar $75,82 \%$ dan penelitian Irwanda yakni $60 \%$ lebih tinggi pada pasien yang merokok. ${ }^{10,8}$ Namun pada penelitian ini tidak ditemukan adanya hubungan bermakna terhadap hipertensi. Hasil ini sejalan dengan hasil penelitian oleh Budi di Semarang pada tahun 2015 karena responden yang memiliki kebiasaan merokok yang ditemukan pada penelitian sangat sedikit. ${ }^{15}$

Diabetes melitus merupakan salah satu penyakit yang dimiliki oleh pasien yang dapat menjadi faktor risiko hipertensi. Pada penelitian ini responden dengan riwayat diabetes mellitus memiliki persentase kejadian hipertensi yang lebih tinggi yakni $60 \%$. Hasil ini sejalan dengan penelitian oleh Silih. ${ }^{9}$ Namun untuk untuk hasil uji statistik pada penelitian ini menunjukkan tidak terdapat hubungan antara riwayat diabetes melitus terhadap kejadian hipertensi. Hasil ini berbanding terbalik dengan hasil penelitian oleh Silih di Pontianak Selatan pada tahun 2012. ${ }^{9}$ Hal ini disebabkan karena responden yang memiliki riwayat diabetes melitus pada penelitian ini sangat sedikit sehingga belum bisa mewakilkan suatu kelompok sebagaimana berbanding terbalik 
dengan penelitian Silih yang mendapatkan prevalensi responden dengan DM yang lebih tinggi. ${ }^{9}$

Adapun variabel yang memiliki hubungan bermakna terhadap kejadian hipertensi pada penelitian ini adalah usia dan obesitas.

\section{Hubungan antara usia responden terhadap kejadian hipertensi}

Hasil uji statistik pada penelitian ini menunjukkan terdapat hubungan antara usia responden terhadap kejadian hipertensi. Hasil sejalan dengan hasil penelitian oleh Sartik di Palembang pada tahun 2017 dan Budi di Semarang pada tahun 2015 yang menunjukkan adanya hubungan antara usia responden terhadap kejadian hipertensi. ${ }^{10,15}$

Usia merupakan salah salah satu faktor risiko hipertensi yang tidak dapat diubah. Pada usia lanjut inflamasi akan sulit diatasi. Hal ini berkaitan dengan peningkatan konsentrasi interleukin-6 (IL-6), C-reactive Protein (CRP), dan tumor necrosis factor alpha (TNF- $\alpha$ ) yang dapat meningkatkan risiko terjadinya penyakit kardiovaskular. Ketiga hal tersebut merupakan biomarker inflamasi yang berkaitan erat dengan proses penuaan dimana semuanya dapat mengalami peningkatan bahkan tanpa adanya infeksi pada seseorang selama penuaan. Saat inflamasi terus terjadi makan produksi ROS juga akan semakin meningkat yang nantinya akan menyebabkan penurunan produksi nitrat oksida (NO). Penurunan produksi NO diketahui menyebabkan disfungsi endotel yang dapat menyebabkan tekanan darah mengalami peningkatan. ${ }^{16,17}$

\section{Hubungan antara obesitas terhadap kejadian hipertensi}

Obesitas dapat menyebabkan penyakit kardiovaskular dengan adanya lemak visceral berlebihan yang menyebabkan sindrom metabolik ditandai dengan perubahan pada metabolisme lemak melalui akumulasi lipid. Cedera ginjal tampaknya dapat terjadi karena mempengaruhi secara signifikan histologi ginjal. Perubahan struktural di dalam ginjal akibat timbunan lemak di sekitar ginjal bersamaan dengan peningkatan tekanan perut dicurigai sebagai penyebab tambahan gangguan reabsorbsi natrium ginjal. Secara khusus pada awalnya obesitas menyebabkan vasodilatasi ginjal dan hiperfiltrasi glomerulus yang bertindak sebagai mekanisme kompensasi untuk mempertahankan keseimbangan natrium meskipun peningkatan reabsorpsi tubular yang bersama dengan peningkatan tekanan darah arteri dan kelainan metabolisme serta faktor-faktor lain seperti peradangan, stres oksidatif, dan lipotoksisitas dapat berkontribusi pada eksaserbasi cedera ginjal atau disfungsi melalui lingkaran setan. Penurunan oksida nitrat (NO) terkait dengan peningkatan stres oksidatif juga dapat terjadi. Secara keseluruhan stres oksidatif serta penurunan NO mengakibatkan vasokonstriksi dan resistensi vaskular yang merugikan sistem kardiovaskular yang dapat menyebabkan hipertensi. ${ }^{18}$

Hasil uji statistik pada penelitian ini menunjukkan terdapat hubungan antara obesitas terhadap kejadian hipertensi. Seperti yang telah dijelaskan sebelumnya bahwa obesitas dapat menyebabkan hipertensi dikarenakan adanya stres oksidatif yang dapat terjadi serta penurunan NO mengakibatkan vasokonstriksi dan resistensi vaskular yang merugikan sistem kardiovaskular sehingga dapat menyebabkan hipertensi. Pada penelitian ini ditemukan adanya hubungan antara obesitas terhadap kejadian hipertensi dengan 16 responden yang memiliki obesitas 9 diantaranya mengalami hipertensi. Hasil ini sejalan dengan penelitian oleh Diana di Sintang pada tahun 2014 bahwa kelompok responden yang mengalami obesitas memiliki risiko yang lebih tinggi untuk terkena hipertensi terkait adanya gangguan pada pembuluh darah. ${ }^{19}$

\section{Kesimpulan}

Berdasarkan hasil penelitian, maka dapat disimpulkan bahwa terdapat hubungan bermakna antara usia dan obesitas terhadap kejadian hipertensi di Puskesmas Rawat Inap sungai Pinyuh. Namun, tidak terdapat hubungan antara jenis kelamin, pekerjaan, tingkat pendidikan, etnis, riwayat penyakit keluarga, kebiasaan merokok, dan diabetes mellitus terhadap kejadian hipertensi di Puskesmas Rawat Inap sungai Pinyuh.

\section{Daftar Pustaka}

1. Kemenkes Republik Indonesia. Infodatin hipertensi. Jakarta: Pusat Data dan Informasi Kementerian Kesehatan RI; 2014.

2. World Health Organization. A global brief on hypertension: silent killer, global public health crises. Geneva: World Health Organization; 2013. 
3. World Health Organization. Noncommunicable diseases country profiles 2018. Geneva: World Health Organization; 2018.

4. Kemenkes Republik Indonesia. Hasil utama riskesdas 2018. Jakarta: Badan Penelitian dan Pengembangan Kesehatan Republik Indonesia; 2018

5. Dinas Kesehatan Kalimantan Barat. Profil kesehatan Provinsi Kalimantan Barat 2017. Pontianak: Pemerintah Provinsi Kalimantan Barat; 2018.

6. Dinas Kesehatan Kabupaten Mempawah. Profil kesehatan Kabupaten Mempawah tahun 2017. Mempawah: Dinas Kesehatan Pengendalian Penduduk dan KB Kabupaten Mempawah; 2017.

7. Dinas Perencanaan Pembangunan Daerah Kabupaten Mempawah. Profil daerah Kabupaten Mempawah tahun 2017. Mempawah: Dinas Perencanaan Pembangunan Daerah Kabupaten Mempawah; 2017.

8. Irwanda TM. Hubungan antara merokok dan hipertensi pada pasien pria di instalasi rawat jalan Klinik Penyakit Dalam RSUD dr. Soedarso Pontianak [skripsi]. Pontianak: Universitas Tanjungpura; 2012.

9. Silih Y. Hubungan antara diabetes melitus dengan kejadian hipertensi di Kecamatan Pontianak Selatan [skripsi]. Pontianak: Universitas Tanjungpura; 2012.

10. Sartik RM, Suryadi, Zulkarnain M. Faktor-faktor risiko dan angka kejadian hipertensi pada penduduk Palembang. Jurnal Ilmu Kesehatan Mayarakat. 2017; 8(3):180-191.

11. Muhammad H, Weta W, Ratnawati NLK. Faktor-faktor yang berhubungan dengan kejadian hipertensi pada kelompok lanjut usia di wilayah kerja
UPT Puskesmas Petang I Kabupaten Badung tahun 2016. Jurnal Medika. 2016; 2(7): 1-23.

12. Everett B, Zajacova A. Gender differences in hypertension and hypertension awareness among young adults. Biodemography Soc Biol. 2015; 61(1): 1-17.

13. Erceg M, Uhernik A, Kern J, Vuletic S. Is there any association between blood pressure and education level? The Cohort study. Coll. Antropol. 2012; Suppl. 1: $125-129$.

14. Bell CN, Thorpe RJ, LaVeist TA. race/ethnicity and hypertension: the role of social support. Am J Hypertens. 2010; 23(5): 534-540.

15. Budi A. Faktor-faktor yang berhubungan dengan kejadian hipertensi tidak terkendali pada penderita yang melakukan pemeriksaan rutin di Puskesmas Kedungmundu Kota Semarang tahun 2014 [skripsi]. Semarang: Universitas Negeri Semarang. 2015.

16. Delacroix S, Chokka RC, Worthley SG. Hypertension: pathophysiology and treatment. J Neurol Neurophysiol. 2014; 1(5): 250

17. Buffford, TW. Hypertension and aging. Ageing Res Rev. 2016; $26: 96-111$

18. Jiang SZ, Lu W, Zong XP, Ruan HY, Liu Y. Obesity and hypertension. Experimental and Therapeutic Medicine. 2016; 12; 2395-9.

19. Diana N, Petrus H, Hendro. Hubungan obesitas dengan hipertensi pada penduduk Kecamatan Sintang Kalimantan Barat. Jurnal Kedokteran Indonesia. 2014; 2(3): $156-8$ 